\title{
METHODICAL ASPECTS OF CIVIL PASSENGER TRAFFIC COSTING
}

\author{
Olena Burdyk ${ }^{1}$
}

\begin{abstract}
Costing is defined as a means of determining the size of the expenditures per unit of production (works, services). The opinions of the scientists on the procedure of costing and, in particular, of the services of motor transport enterprises engaged in civil passenger traffic are reported. The normative documents used by motor transport enterprises while drawing up transportation costing and tariff imposing are considered. The estimation of expenses is carried out and the scheme of tariff formation by the motor transport enterprise is developed. It is determined that costing depends on the correct planning of the transportation prime cost, which is calculated based on the data on the planned volumes of passenger traffic by motor transport enterprises. It is established that there is no single list of articles for passenger traffic costing, as the motor transport enterprise has its activity characteristics, so it individually defines this list in the Order on Accounting Policy. It should be noted that for correct calculation it would be appropriate to regulate it with normative documents with the implementation of the classification of enterprises into groups according to their activity profile. Such a normative document would make it possible to reliably justify tariff imposing by a particular motor transport enterprise. It is found out that the data of surveys of passenger flows are quite relative, so without a clear definition of the number of transported passengers, it is impossible to calculate either the reliable prime cost of transportation or to form a reasonable tariff. Passenger traffic costing as well as cost accounting requires special attention because tariffs of the motor transport enterprise are formed based on the calculated prime cost. The study showed that at present the activity of many motor transport enterprises is unprofitable, which is caused by the high prime cost of passenger traffic and will require another increase in fares. The article aims to consider the methodological approaches to passenger traffic costing, to analyze the cost structure of the motor transport enterprise to identify shortcomings and provide proposals for cost optimization and ensure their profitable operation. Methodology. To achieve this goal, the necessary tools of scientific research methods are used: dialectical method of cognition - to clarify the meaningful characteristics of expenditures and calculate the cost of production (works, services); observation - to study the state and trends of cost changes and the order of tariff formation by motor transport enterprises; grouping and economic analysis of costs -to process analytical information for further use while making management decisions aimed at ensuring profitable activity; causal relationships, concretization - to determine the information needs of users on costs; systematization and generalization - to develop proposals for improving the methods of cost accounting and traffic costing. Practical results. Based on the analysis, the normative method of costing as an effective means of cost management and ensuring the rational use of resources of the motor transport enterprise is determined. Value/originality. It is established that clear accounting of the number of transported passengers is required to determine the reliable prime cost of transportation and form reasonable transportation tariffs.
\end{abstract}

Key words: cost accounting, costing, tariff, motor transport enterprise, passenger traffic.

JEL Classification: M14

\section{Introduction}

The improvement of market economic mechanisms, the use of modern methods of planning, pricing, and management of production processes require special attention to the formation and composition of operating costs, production costs (works, services), and determining their economic nature and accounting. The cost of production (works, services) is an important indicator of activity, as it affects the financial result and characterizes the degree of achievement of the strategy of cost optimization to strengthen the enterprise

\footnotetext{
Corresponding author:

${ }^{1}$ Lviv University of Trade and Economics, Ukraine.

E-mail: olenatka@ukr.net

ORCID: https://orcid.org/0000-0002-3002-7672
} 
competitiveness. The civil passenger traffic costing is important from the standpoint of forming an information basis for imposing tariffs. The cost price represents a monetary expression of the cost of providing passenger transportation services. Proper transportation costing prevents the occurrence of excessive costs and is important for the information management of the enterprise, helping to make substantiated decisions regarding the improvement of business processes and provision of new services.

\section{Brief literature review}

The issues of cost accounting and the cost of production (works, services) are reflected in the scientific works by both foreign and domestic scientists. Considering the method of cost accounting, it can be characterized as a set of techniques that provide the fixation and accounting of operating costs which allow to determine the actual cost of production and form the necessary information to control these processes in terms of cost objects, to determine the composition and size of expenditures by certain types of production (works, services).

Calculation methods are a set of methods and techniques needed to calculate the cost of specific production (works, services) and a set of methods for allocating expenses by costing articles and referring them to the object of calculation. As an element of the accounting method, the calculation involves the estimation of the costs of the enterprise for the acquisition or manufacturing of certain types of tangible assets, production (works, services), and the cost of their sale.

The methodological recommendations of the Ministry of Transport of Ukraine define the concept of transportation prime cost as a monetary expression of current costs directly related to the preparation and implementation of the process of passenger traffic, as well as the performance of works and services that provide transportation. At the same time, this document gives an interpretation of costing as the determination of the number of expenditures in cash for the production of the unit of a particular service by certain types of costs. Also, it is noted that the calculation determines:

- prime cost of a services unit;

- the whole range of services;

- prime cost of production by individual structural divisions;

- by various production processes;

- as a whole at the enterprise.

After reading the above document, it should be noted that there is no meaningful definition of costing in these guidelines which would relate to passenger vehicles. This means that each enterprise independently chooses the composition and content of cost accounting articles. However, the authors believe that for the correct and complete calculation it would be more appropriate to regulate it by normative documents with the implementation of the classification of enterprises into groups according to their activity profile. Such a normative document would make it possible to reliably justify imposing a tariff by a particular motor transport enterprise. The economic substantiation of the level of a tariff for the use of transport products is a difficult task that requires in-depth theoretical research and development of methodological approaches and comprehensive decisions (Mishchenko et al., 2018).

The use of the normative method of costing recommended by the Methodical Recommendations of the Ministry of Transport of Ukraine allows detecting the deviations of actual costs from the established norms with subsequent analysis of the deviations, the results of which allow clarifying the reasons for these deviations or reviewing the existing norms. The costing of services of the motor transport enterprise does not require the use of complex calculations, since these products are mass-produced, manufactured simply and there is no work in progress inventory at the end of the reporting period (Dankiv et al., 2013).

Adherence to the rules of cost accounting, defined by the relevant regulations, involves a continuous verification of actual and planned data used by businesses to calculate tariffs (Davydov et al., 2009). It is important to take into account two main factors in the cost accounting process, due to which the motor transport enterprise can increase its profitability: solving the problem of reimbursement of losses from the transportation of privileged passengers and reducing its operating costs (Plikus et al., 2002).

It is not possible to calculate the reliable cost of transportation and form a reasonable traffic tariff without a clearly defined number of transported passengers. Therefore, to accurately determine the level of a tariff, it is necessary to improve the methods of data collection. Since passenger traffic is a key to calculating the fare per person the problem is that it can be calculated only roughly (Barabash et al., 2015). At present, there is still no clear norm that would oblige local governments to survey passenger traffic with a certain frequency when setting tariffs for passenger transportation or require the initiator to change the tariff to provide the results of such a survey (Zaviiskyi, 2017).

\section{Results}

Costing depends on the correct planning of transportation cost, which is calculated based on the data on the volume of planned passenger traffic by the motor transport enterprise. Thanks to the costing data it 
Table 1

Estimation of the cost structure for the provision of services

by Lviv municipal motor transport enterprise № 1 in 2018-2019

\begin{tabular}{|l|c|c|c|c|c|c|}
\hline \multirow{2}{*}{ Article name } & \multicolumn{2}{|c|}{2018} & \multicolumn{2}{c|}{2019} & \multicolumn{2}{c|}{ Deviation (+, - } \\
\cline { 2 - 8 } & $\begin{array}{c}\text { sum thousand } \\
\text { UAH }\end{array}$ & $\begin{array}{c}\text { specific weight, } \\
\%\end{array}$ & $\begin{array}{c}\text { sum thousand } \\
\text { UAH }\end{array}$ & $\begin{array}{c}\text { specific weight, } \\
\%\end{array}$ & $\begin{array}{c}\text { sum thousand } \\
\text { UAH }\end{array}$ & $\begin{array}{c}\text { specific weight, } \\
\%\end{array}$ \\
\hline Salary expenses & 1 & 2 & 3 & 4 & 5 & 6 \\
\hline Deductions for social concerns & $(33,264)$ & 18.34 & $(67,606)$ & 18.92 & $-34,342$ & 0.58 \\
\hline Depreciation of non-current assets & $(49,930)$ & 3.27 & $(13,224)$ & 3.70 & $-7,294$ & 0.43 \\
\hline Raw and auxiliary materials & $(82,112)$ & 27.22 & $(125,886)$ & 35.22 & $-76,512$ & 8.0 \\
\hline Production services & $(7,614)$ & 45.27 & $(118,923)$ & 33.27 & $-36,811$ & -12.0 \\
\hline Other expenses & $(3,094)$ & 1.70 & $(15,618)$ & 4.37 & $-8,004$ & 0.17 \\
\hline Total & $(181,388)$ & 100.0 & $(357,401)$ & 100.0 & $-176,013$ & 2.82 \\
\hline
\end{tabular}

Source: Financial reporting by Lviv Municipal Motor Transport Enterprise № 1

is possible to determine the number of costs per unit of work performed. The grouping of costs is carried out by the following economic elements:

- material costs;

- salary expenses;

- deductions for social concerns;

- amortization of fixed assets and intangible assets;

- other operating expenses.

Given this classification, the authors will assess the cost structure of the motor transport enterprise (Table 1).

Based on the data in Table 1 it can be concluded that the costs of Lviv municipal motor transport enterprise №1 in 2019 increased significantly compared to 2018, causing an increase in the cost of services. Graphically, these changes are shown in Figure 1.
As it can be seen, the largest share in the cost structure in 2019 fell on the depreciation of non-current assets (35.22\%) and raw and auxiliary materials (33.27\%).

It is important to correctly group expenses by costing articles, as this will allow to organise:

- analytical cost accounting;

- calculation of costs in terms of structural units of the motor transport enterprise;

- costing of certain types of transportation.

Thus, the production cost of transportation includes the following types of costs: general production, direct material, and direct labor costs, other direct costs. At the same time, motor transport enterprises are allowed to make changes to the above range of costs both combining them and selecting standard costing articles. This is due to the peculiarities of

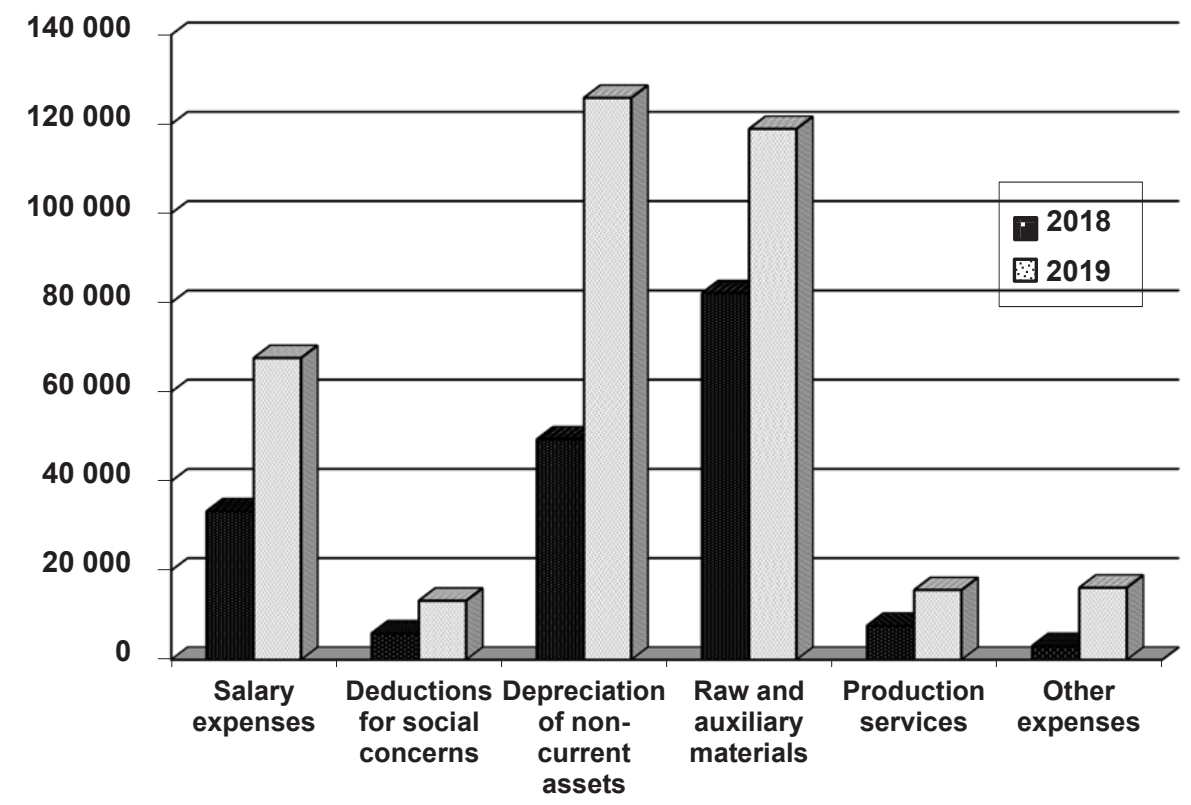

Figure 1. Graphic interpretation of dynamic changes in the structure of operating costs of Lviv Municipal Motor Transport Enterprise № 1 in 2018-2019 
transportation organisation and the specifics of the organisational structure of enterprises, as well as the specific weight of expenditures in the prime cost of certain types of transportation.

There is no single list of articles for passenger traffic costing, as each motor transport enterprise has its characteristics, so companies individually define this list in the Order on Accounting Policy. The following methods of costing are defined by the methodical recommendations on the formation of the prime cost of transportations: normative, standard-costing, job order costing, or simple calculation of expenses. However, the Methods for calculating tariffs for civil passenger traffic services state that for planning and calculation of costs it is necessary to apply the normative method, the main elements of which are the accounting of costs by certain types of transportation according to current regulations.

Due to the normative method of production costing, cost management is carried out, which ensures the rational use of resources by the motor transport enterprise and, in turn, will help reduce the prime cost of transportation. This is especially important in the conditions of unprofitable activity of some motor transport enterprises.
Particular attention should be paid to the methods of the formation of tariffs for transportation services (Figure 2), which are developed based on the order of the Ministry of Transport of Ukraine № 1175 “On approval of the Methods for calculating tariffs for civil passenger traffic" dated November 17, 2009 and is based on the information on enterprise costs. According to the order, the tariff on public bus routes is considered to be the cost of a single trip for one passenger.

The figure shows that the exact formation of tariffs is based on the data on actual and planned costs. That is why it is important to comply with the rules of cost accounting, the order of reflection of which in accounting is regulated by $\mathrm{P}(\mathrm{S}) \mathrm{A}$ (Provisions (Standards) of Accounting) 16 "Costs".

The tariff must be formed by the motor transport enterprise according to the actual performance or the results of the survey of passenger flows. The study of public demand for transportation is carried out by:

- distribution, collection, and processing of questionnaires;

- use and analysis of appeals of legal entities and individuals;

- survey of passenger flows.

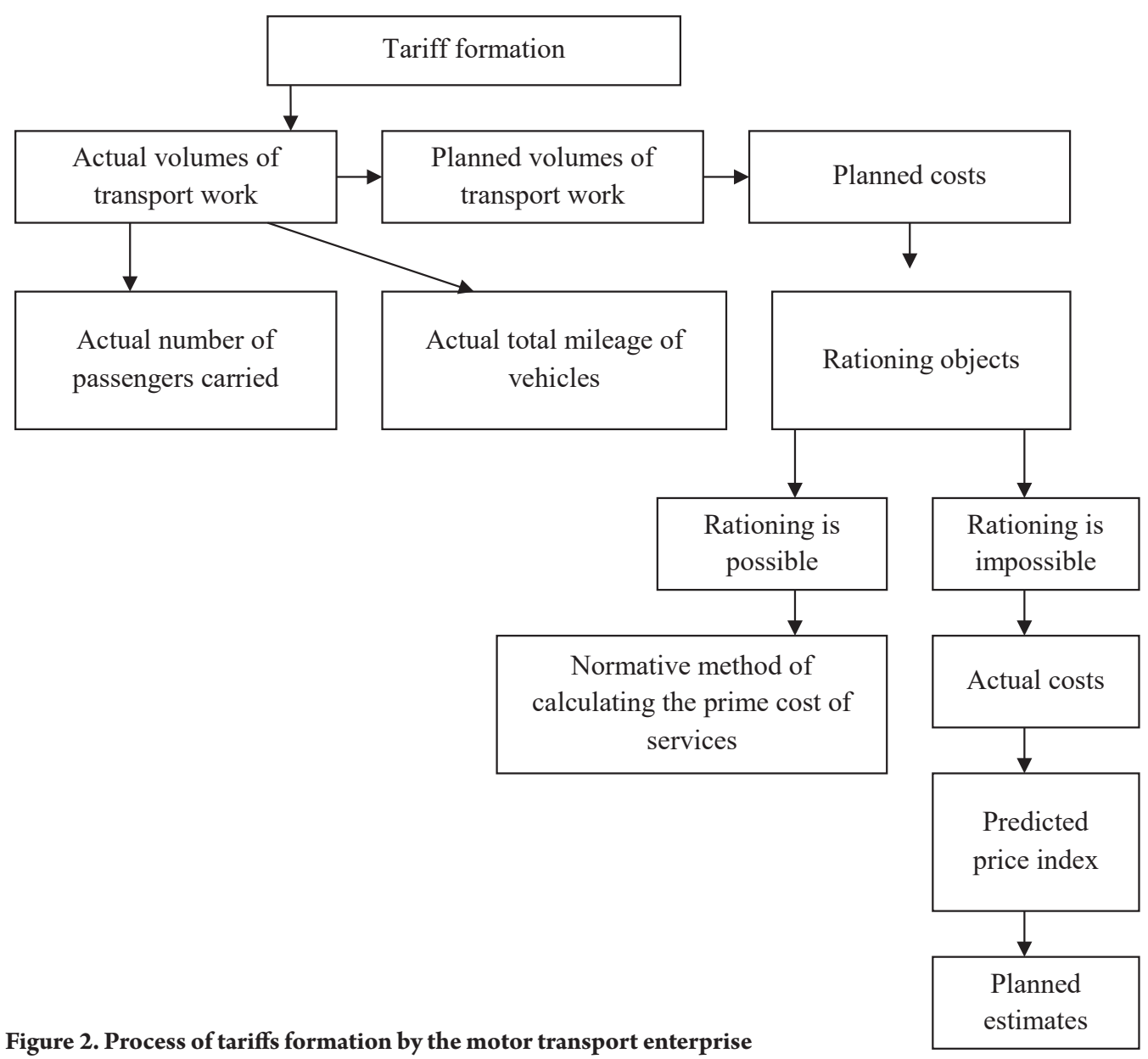


Data from surveys of passenger flows are quite relative and should not be relied on completely. Obtaining information on real passenger flows using modern data capture tools is of key importance to calculate the cost of passenger traffic.

\section{Conclusions}

Thus, civil passenger traffic costing as well as cost accounting requires special attention since the tariffs of motor transport enterprises are formed based on the calculated cost. The recommendations for cost accounting and costing of motor transport enterprises ensure the completeness of reflection in the accounting management system of data on expenditures and their use for management purposes, taking into account the conditions of economic activity and the impact of external and internal factors. The study shows that at present, the activity of many motor transport enterprises is unprofitable due to the high prime cost of passenger traffic. Therefore, the prospect of further research is to conduct a comprehensive analysis of the costs of providing passenger transportation services to identify reserves for their optimization.

\section{References:}

Metodychni rekomendatsii z formuvannia sobivartosti perevezen (robit, posluh) na transporti. Ministerstvo transportu Ukrainy vid 05.02.2001 r. № 65. Available at: https://zakon.rada.gov.ua/rada/show/v0065361-01\#Text Nakaz "Pro zatverdzhennia Metodyky rozrakhunku taryfiv na posluhy pasazhyrskoho avtomobilnoho transportu" Ministerstva transportu ta zviazku Ukrainy vid 17.11.2009 r. № 1175 zi zminamy ta dopovnenniamy stanom na 08.01.2013 r. Available at: https://zakon.rada.gov.ua/laws/show/z1146-09

Polozhennia (standart) bukhhalterskoho obliku 16 "Vytraty": nakaz Ministerstva finansiv Ukrainy vid 31 hrudnia 1999 roku № 318. Available at: https://zakon5.rada.gov.ua

Pro zatverdzhennia Poriadku orhanizatsii perevezen pasazhyriv ta bahazhu avtomobilnym transportom: nakaz Ministerstva infrastruktury Ukrainy № 480 vid 15.07.2013. Available at: https://zakon.rada.gov.ua/laws/show/ z1282-13\#Text

Finansova zvitnist za rik, shcho zakinchyvsia 31 hrudnia 2019 roku vidpovidno do mizhnarodnykh standartiv finansovoi zvitnosti razom zi zvitom nezalezhnoho audytora Lvivskoho komunalnoho avtotransportnoho pidpryiemstva № 1. Available at: https://atp1.lviv.ua/wp-content/uploads/Finansova-zvitnist-LK-ATP-1-2019.pdf

Barabash, O. O., \& Bohachenko, M. V. (2015). Mekhanizm vyznachennia optymalnoho rivnia taryfiv na pasazhyrski perevezennia [Mechanism for determining the optimal level of tariffs for passenger traffic]. Naukovyi visnyk Uzhhorodskoho universytetu, vol. 1(3), pp. 23-28.

Davydov, H. M. (2009). Audyt taryfiv na perevezennia pasazhyriv u miskomu spoluchenni [Audit of tariffs for passenger transportation in urban traffic]. Naukovi pratsi Kirovohradskoho natsionalnoho tekhnichnoho universytetu, vol. 15, pp. 337-341.

Dankiv, Y. Ya. (2013). Oblik vytrat i formuvannia sobivartosti avtotransportnykh perevezen [Cost accounting and formation of traffic prime cost]. Proceeding of the Aktualni problemy oblikovo-analitychnoho protsesu $v$ upravlinni pidpryiemnytskoiu diialnistiu: materialy I Mizhnarodnoi naukovo-praktychnoi internet-konferentsii (Ukraine, Mukachevo, November 28, 2013). Available at: http://msu.edu.ua/wp-content/uploads/2014/01/\%D0\%97\%D0 \%B1\%D1\%96\%D1\%80\%D0\%BD\%D0\%B8\%D0\%BA-\%D1\%82\%D0\%B5\%D0\%B7-2013-17.01.14.pdf

Zaviiskyi, O. I. (2017). Investytsiino-innovatsiina aktyvnist posluh avtotransportnykh pidpryiemstv: stan ta pereshkody [Investment and innovation activity of the services of motor transport enterprises: state and obstacles]. Instytut rehionalnykh doslidzhen imeni M. I. Dolishnoho NANU, vol. 3(125), pp. 22-27.

Mishchenko, M. I. (2018). Vdoskonalennia metodolohii taryfoutvorennia yak zasib pokrashchennia finansovoho stanu pidpryiemstv miskoho transportu [Improving the methodology of tariff formation as a means of improving the financial condition of urban transport enterprises]. Naukovyi visnyk Odeskoho natsionalnoho ekonomichnoho universytetu, vol. 9(261), pp. 102-116.

Plikus, I. Y. (2002). Problemy formuvannia taryfiv na pasazhyrski avtotransportni perevezennia [Problems of the formation of tariffs for civil passenger traffic]. Materialy Druhoi vseukrainskoi naukovo-praktychnoi konferentsii "Ukraina naukova 2002", vol. 6, pp. 38-40. 